\title{
A „HogYAN TOVÁBB” KÉRDÉSE ROMÁN NEMZETISÉGÜ EGYETEMI HALLGATÓK KÖRÉBEN
}

\author{
NAGY EDITH
}

\begin{abstract}
One of the topic of the research was career orientation. A questionnaire survey was carried out among university students and later within the Career Image and Work Value Research Project which took place within the University of Debrecen. The questionnaire consisted of 53 questions. The questionnaire could be divided into five major topics. The questions were related to the preliminary, previous school records, college and university experiences, the chosen vocation, profession, and family.

The research was carried out at Babes-Bolyai University of Cluj-Napoca. 73 students took part in the research, they were all ethnic Romanians. Regarding their gender identity there were 9 male students and 64 female undergraduates.
\end{abstract}

Keywords: career orientation, decision, targets, guidance, prestige, information, professional, self-realization, admission

DOI: $10.19055 / \mathrm{ams} .2013 .4 / 10 / 7$

Dolgozatvezető tanár: Dr. Müller-Fábián Andrea egyetemi docens, BBTE

\section{BEVEZETÉS}

A 12. osztályos diákok körében nem csak az elöttük álló érettségi játszik nagy szerepet, hanem a nagy döntés és választás felelössége is, hogy hogyan tovább. Igazán nagy kérdés manapság, hogy a fiatalok miként választanak egyetemet a líceum elvégzését követően. Mit tartanak szem előtt? Kérnek-e tanácsot? Nagy álmokat szeretnének-e megvalósítani? Szociális munkások körében számos esetben kérdés, hogy a fiatal személy rendelkezik-e a kellő tulajdonságokkal melyek szükségesek az adott szakma gyakorlásához? Miképpen lehet ezeket felmérni? Egyáltalán fel kell-e mérni? Miképpen döntenek a fiatalok a szociális munka és egyéb szakok mellett? Milyen belső indíttatásuk, motivációjuk van. Kérnek-e tanácsot? Fontos-e az elkötelezettség érzése? Hogyan jutnak kellő információkhoz? Van-e magyarázat arra, hogy a pályaválasztás során a többség, akik a szociális munka szakot választják, az nő nemü? 
Számos kérdésre próbáljuk keresni a választ a kutatásunk során. Kíváncsiság és érdeklödés van bennünk. A kutatásban részvevők többségében szociális munka szakot és más társadalomtudományi, bölcsésztudományi, teológia, és jogi szakot végző diákok alkotják.

\section{ELMÉLETI HÁTTÉR}

Kezdetben a pályaorientáció fogalmát szeretnénk meghatározni. A pályaorientáció egy összetett szó, az elötagja közismert kifejezés, pálya, utótagjának jelentése tájékozódást, eligazodást jelent (Bakos, 1986). A pályaorientáció fogalmat, úgy tudjuk meghatározni, mint a szakmákkal kapcsolatos információ gyüjtést, tájékozódást, keresgélést, kutakodást, amely a különböző szakmák közötti eligazodást és megkülönböztetést is jelenti. A pályaorientáció jelentése magába foglalja az egyén személyes kompetenciáit, készségeit és ezek megszerzését, mely előkészíti és képessé teszi az egyént az általa választott szakkal együtt járó kihívásokban való megfelelésre, legyen az egyéni pálya, karrier, egyén és környezetének megfeleltetését (R. Bögös, V. Dávid, 2003). A pályaorientáció kérdésében nem csak a különböző szakmák jellemzőiröl beszélünk, hanem az egyén adottságairól, környezetéböl és társadalomból szerzett ismereteiröl is. A pályaorientáció segít összhangba hozni az egyéni készségeket, a társadalmi igényeket és a választott szakmát, nem egy egyszeri esemény, hanem folyamat amely a megfelelő döntés megszületését készíti elő. A jó döntés meghozásában négy dolog szükséges: reális énkép, információk a szakmákról, munkaerő-piaci ismeretek, képzési lehetőségek a jövőre nézve (R. Bögös, V. Dávid, 2003).

\section{A KUTATÁs FöBb EREDMÉNYeI}

\section{A hallgatók szoci-demográfiai jellemzöi}

A kutatás egyik kérdése a pályaorientáció. Kérdőíves kutatást végeztünk egyetemisták körében és a továbbiakban a Debreceni Egyetemen folyó Pályakép és Munkaérték Kutatási Projekt keretén belül. A kérdőív 53 kérdésböl épül fel. Összesen öt nagy témakörre bonthatjuk fel a kérdéseket. A kérdések a felvételire, eddigi iskolai pályafutásra, egyetemre és egyetemi tapasztalatokra, választott szakjára,és szakmájára és családjára vonatkoznak.

Az elért eredményekből néhány ismérvet mutatok be. A kérdőív tíz kérdésből állt. $\mathrm{Az}$ eredmények bemutatása során kiemeltem azon ismérvek eredményeit, amelyeket fontosnak véltem a pályaorientáció témakörben.

A kutatást Kolozsváron a Babeş-Bolyai Tudományegyetemen végeztük. A kutatásban megkérdezett hallgatók száma 73, nemzetiségüket tekintve román nemzetiségüek. Nem szerinti megoszlás alapján 9 férfihallgató és 64 hallgatónő.

A továbbiakban a megkérdezettek kor szerinti megoszlását mutatom be. A legfiatalabb egyén 19 éves, a legidősebb 49 éves. A hallgatók többsége a 19,-22 éves, az idősebb korosztálybeliek vannak kisebb arányban. 
A megkérdezett hallgatók a Babeş-Bolyai Tudományegyetem négy karának diákjai: 78, $1 \%$ a Szociológia és Szociális Munka karról, 1,4\% a Bölcsészettudományi és Mủvészeti Karról, 2,7 \% a Társadalomtudományi, illetve Jogi Karról, valamint 15,1\% a Teológiai, Egyházi, és Vallási Karról. ;2,7\% erre a kérdésre nem válaszolt. A megkérdezett személyek nagymértékben szociális munka szakos hallgatók.

\section{Pályaválasztás, egyetemi és egyetem utáni célok}

A következö kérdés, az egyetemi felvételi, illetve a felvételit követö sikeres bejutással kapcsolatos: a diák hányadik próbálkozásra jutott be sikeresen az adott főszakra. Számos szak van és eltérö felvételi elöírások. A pályaválasztásban fontos a felvételin való siker vagy kudarc szerepe.

Az egyetemi bejutásnak a sikeressége alapvető fontosságú egy egyén életében. Fenn áll a kérdés, hogy sikerként, vagy kudarcként éli meg az egyetemi felvételit. A válaszadók esetében megfigyelhető, hogy 76.7\%-kukat első jelentkezésre felvették.

A következő kérdés, hogy honnan szerzett információkat a szakkal kapcsolatosan. A megkérdezettek $8,2 \%$ vélekedett úgy, hogy a média nagy szerepet játszott az információszerzésben. 53,4\% úgy vélekedett, hogy a média egyáltalán nem játszott szerepet az információszerzésben. 13,7\% a megkérdezetteknek azt állította, hogy kis mértékben szerepe volt a médiának és végül $4,1 \%$ minősített döntő szerepet a médiának. Az információ forrás kérdésben meglepő módon nem a média játszott nagy szerepet a megkérdezettek körében.

Arra a kérdésre keresve a választ, hogy a pályaválasztás folyamatában kiknek a tanácsait vették alapul, illetve hogy a döntés egyéni önmegvalósítás céljából született-e, a válaszadók 9,6\% válasza az volt, hogy a szülők tanácsolták ezt a szakot, 30,1\% vélekedett úgy, hogy nem a szülők tanácsolták. $26 \%$ esetben pedig a szülők tanácsa nagy szerepet játszott, 17\%-ban pedig kis szerepet tulajdoníthatunk a szülöi tanácsoknak. (1. táblázat)

A következőkben azokat az válaszokat emelem ki, melyek arra a kérdésre keresnek magyarázatot, hogy a megkérdezettek döntését a választott szak mellett meghatározzae az, hogy milyen mértékben tudják megvalósitani elképzeléseiket. 12 személy válasza az volt, hogy egyáltalán nem meghatározó jellegü az, hogy milyen mértékben sikerül majd megvalósítani elképzeléseiket, 12 személy esetében kevésbé meghatározó jellegü, 24 személy úgy vélekedett, hogy nagyrészt meghatározó és 16 személy számára döntően meghatározó. 2 személy a nem tudja válaszlehetőséget jelölte meg a kérdőív kitöltése során.

A szerzett diplomával jól lehet-e keresni kérdésben 46,6\% -ban egyáltalán nem, majd ezt követte az egy kicsit válaszlehetöség, amelyet a válaszadók $30,1 \%$ jelölte be, $6,8 \%$ nagyrészt és végül $2.7 \%$ a döntően választ adták a megkérdezettek közül.

Azzal a feltételezéssel kapcsolatosan, hogy az egyetem kiválasztásakor a szakon való tanulás oka a hasznositható ismeretek elsajátitása, a megkérdezettek 45,2\% vélekedett igennel és 49,3\% a nem válasszal. Ez esetben megfigyelhetö, hogy az igen és nem válaszok között nagyon kicsi a különbség 4,1\%. 
1.számú táblázat: Mennyire jellemző, hogy

a szülei tanácsára választotta az egyetemet

\begin{tabular}{|l|c|c|}
\hline nem tudja, nem válaszolt & 1 & $1,4 \%$ \\
\hline egyáltalán nem & 22 & $30,1 \%$ \\
\hline csak kis mértékben & 17 & $23,3 \%$ \\
\hline nagy szerepet játszott & 19 & $26,0 \%$ \\
\hline döntő mértékű & 7 & $9,6 \%$ \\
\hline Összesen & 66 & $90,4 \%$ \\
\hline System & 7 & $9,6 \%$ \\
\hline Összesen & 73 & $100,0 \%$ \\
\hline
\end{tabular}

Forrás: Debreceni Egyetemen folyó Pályakép és Munkaérték

Kutatási Projekt-kérdőív 24 számú kérdése

A második ismérv a választott szakon meglevő magas színvonal. A válaszadók esetében $34,2 \%$-ban játszott szerepet és $60,3 \%$ esetében nem játszott szerepet az említett ismérv. A színvonalat, mint ismérvet, azért emeltem ki, mivel alapvető szerepet tölt be a mindennapi életben, valamint más szakterületeken is az elért színvonal. A megkérdezettek fiatal egyetemisták, akik még tanulmányaikat folytatják, ezért feltételezhető, hogy a magas színvonalnak a fontosságával és értékével még nem találkoztak. A magas színvonalnak a munkaerő piacon van fontos szerepe.

Már az egyetemi tanulmányok során felmerül a kérdés, hogy az adott szak, mely keretén belül az egyén a tanulmányait folytatja, elösegiti-e az egyént az elsajátított ismeretekkel a jövőre nézve a megfelelö szakmai felkészülésben. A kérdőívben szereplö kérdés azt méri, hogy az egyén számára fontos-e az, hogy a szak elősegítse a felkészülésben. A megkérdezett egyének közül $60,08 \%$ / -ban vélekedtek úgy, hogy számukra nagyon fontos, $2,89 \%$-ban egyáltalán nem fontos, 30,43\%-ban fontos és végül 5.79\%ban kevésbé fontos.

A szakmával kapcsolatos ismeretek elsajátításához fontos szerepet játszik az egyéni kutatások, beavatkozások, amelyeket az egyetemi hallgató, már egyetemi tanulmányai során elvégezhet, Ebben a kérdésben kiemelt szerepet játszanak a Konferenciák melyek keretén belül lehetöség nyílik arra, hogy az egyetemi hallgatók a kutatásaikat bemutatják. Ezért emeltem ki a következő kérdésre kapott válaszokat,amely tartott-e már konferencián elöadást kérdésre. A válaszadók aránya a következöképpen oszlik meg:70 válaszadó közül $86 \%$ nemmel és $14 \%$ a igennel válaszolt.

A következő kérdés ami szinten az egyetemi tanulmányok ideje alatt folytatott szakmai tapasztalattal kapcsolatos, az a tanárai kutatásaiban való részvétel kérdése. A megkérdezettek közül $17 \%$ válasza volt igen, azaz részt vesznek kutatásokban és $83 \%$ 
nem. Szakmai tapasztalat igen nagy szerepet játszik az elméleti ismeretek elsajátítása mellett. Nagyszerủ ezt látni, hogy diákok konferenciákon való részvételének és tanári kutatásban való részvétel száma is egy magas arány. Diákok már egyetemi tanulmányaik idejében nagy arányban elsajátítják a gyakorlati részét is a szakmájuknak.

A tanulmányainak elvégzése után a megkérdezettek $34,2 \%$ szeretne a szakmájával összefüggő területen dolgozni, 23,3\% a szakjának megfelelő szakmában, 9,6\% mindegy mit dolgozna, csak jól fizessék, 9,6\% olyan területen dolgozna, ami nem a szakjával összefüggö, 2,7\% nem szeretne dolgozni, mert külföldön szeretné folytatni tanulmányait és $13,7 \%$ nem gondolkodott még erről.

A szakterület kiválasztását követően fontos a település kiválasztása. Kérdés, hogy a nagy városon elvégzett egyetemi tanulmányokat követően az egyén miként dönt, hogyan képzeli el jövőjét. (2. táblázat)

2.számú táblázat: Gondolkodott-e már azon, hogy végzés után milyen szakmában dolgozna?

\begin{tabular}{|l|c|c|}
\hline Igen, a szakjának megfelelő szakmában & 17 & $23,3 \%$ \\
\hline Igen, a szakjával összefüggő területen & 25 & $34,2 \%$ \\
\hline Igen, de nem a szakjával összefüggő területen & 7 & $9,6 \%$ \\
\hline Mindegy mit, csak jól fizessen & 7 & $9,6 \%$ \\
\hline Nem, mert még tanulni akar egy újabb szakon & 1 & $1,4 \%$ \\
\hline Nem, mert még külföldön akar tanulni & 2 & $2,7 \%$ \\
\hline Nem, mert PhD-kurzusra akar jelentkezni & 1 & $1,4 \%$ \\
\hline Nem gondolkodott még erről & 10 & $13,7 \%$ \\
\hline Egyéb & 1 & $1,4 \%$ \\
\hline Összesen & 71 & $97,3 \%$ \\
\hline
\end{tabular}

Forrás: Debreceni Egyetemen folyó Pályakép és Munkaérték Kutatási Projekt-kérdőív 34 számú kérdése

A tanulmányok befejezését követően alapvető kérdés a diákok körében, hogy van-e már elképzelése arról, hogy az egyetem elvégzése után milyen településen dolgozna a legszívesebben kérdésre, a válaszadók 1.4\% a fővárosban, 31,5\% Kolozsváron, $11 \%$ máshol és 19,2 külföldön dolgozna szívesen. Kereshetünk magyarázatokat és érveket, hogy mi okból kifolyólag nyerhettük ezeket az eredményeket. A diákok magas arányban Kolozsváron szeretne elhelyezkedni. Kolozsváron folytatják az egyetemisták tanulmányaikat, így számos kapcsolat kialakul. Legyen az baráti vagy szakmai kapcsolatok. A megszokásnak is alapvető kérdése van, és maga a Kolozsvár mint nagy város a színességével, lehetőségeivel melyek egy fiatal egyén számára vonzónak bizonyulnak. A külföldön való munkát, mint válasz lehetőséget 19,2\% -ban jelölték be a megkérde- 
zettek közül. Vonzó a fiatalok körében a külföldön való elhelyezkedés, talán nagyobb lehetőségeket látnak és a javadalmazás is szerepet játszhat. Ami számomra kissé meglepő az eredményeket figyelve, azoknak a nagyon alacsony aránya, aki a fóvárosban dolgozna (1,4\%), és relatíve sokan pedig a máshol válaszlehetőséget jelölte be (11\%).

\section{Pályaválasztás}

A döntéseink meghozásához számos tényező hozzájárul Információk, ismeretek, egyéni képességek. A következőkben a kérdések a pályaválasztás kiválasztásában és maga a döntésre vonatkoznak. Ezekkel kapcsolatos ismereteket emelném ki, melyek hozzájárultak és elősegítették az egyén döntését. Legyen ez külső vagy belső tényező.

A megkérdezettek válaszaiból láthatjuk, hogy 1,4\%-uk vélekedett úgy, hogy pályájának megválasztásakor a másokon való segítség csak kis mértékben volt fontos, 8.4\%uk vélekedett úgy, hogy eléggé fontos volt, 32,3\%-uk úgy, hogy fontos volt és $57,7 \%$ uk nagyon fontosnak vélte a másokon való segítség lehetőségét. Mekkora a szerepe a választásban a tekintélynek (3. táblázat)

3.számú táblázat Tekintélyszerzés a munkával

\begin{tabular}{|l|c|c|}
\hline Egyáltalán nem fontos & 2 & $2,7 \%$ \\
\hline Kicsit fontos & 5 & $6,8 \%$ \\
\hline Eléggé fontos & 9 & $12,3 \%$ \\
\hline Fontos & 28 & $38,4 \%$ \\
\hline Nagyon fontos & 24 & $32,9 \%$ \\
\hline Összesen & 68 & $93,2 \%$ \\
\hline
\end{tabular}

Forrás: Debreceni Egyetemen folyó Pályakép és Munkaérték Kutatási Projekt-kérdőív 40 számú kérdése

A következő ismérv, a tekintély fontossága a munka során. 2.7\% a megkérdezettek számára a tekintély egyáltalán nem fontos, $6,8 \%$-nak kicsit fontos, 12,3\%-nak eléggé fontos, $38,4 \%$ fontos és végül 32,9\%-nak a megkérdezettek közül nagyon fontos a tekintély.

A következö ismérv az önmegvalósitás fontossága. 1,4\% a megkérdezettek körül vélekedett úgy, hogy az önmegvalósítás egyáltalán nem fontos és $46,6 \%$ számára fontos. (4. táblázat)

Előző kérdés melyet kiemeltem, az az egyén önmegvalósításával kapcsolatos. Az önmegvalósítási témakör arról mondhatjuk, hogy egyéni szinten jelenik meg. A következő a kérdéskör pedig az már nagyobb dimenziót foglal magába amely Szebbé teheti a világot kérdést veti fel. A továbbiakban ezen kérdésekre kapott eredményeket fogom bemutatni. (5. táblázat) 
4.számú táblázat Önmegvalósítás fontossága

\begin{tabular}{|l|c|c|}
\hline Egyáltalán nem fontos & 1 & $1,4 \%$ \\
\hline Kicsit fontos & 3 & $4,1 \%$ \\
\hline Eléggé fontos & 7 & $9,6 \%$ \\
\hline Fontos & 25 & $34,2 \%$ \\
\hline Nagyon fontos & 34 & $46,6 \%$ \\
\hline Összesen & 70 & $95,9 \%$ \\
\hline Nem válaszolt & 3 & $4,1 \%$ \\
\hline Total & 73 & $100,0 \%$ \\
\hline
\end{tabular}

Forrás: Debreceni Egyetemen folyó Pályakép és Munkaérték Kutatási Projekt-kérdőiv

5..számú táblázat Szebbé teheti a világot

\begin{tabular}{|l|c|c|}
\hline Kicsit fontos & 1 & $1,4 \%$ \\
\hline Eléggé fontos & 8 & $11,0 \%$ \\
\hline Fontos & 23 & $31,5 \%$ \\
\hline Nagyon fontos & 39 & $53,4 \%$ \\
\hline Total & 71 & $97,3 \%$ \\
\hline Nem válaszolt & 2 & $2,7 \%$ \\
\hline Total & 73 & $100,0 \%$ \\
\hline
\end{tabular}

Forrás: Debreceni Egyetemen folyó Pályakép és Munkaérték Kutatási Projekt-kérdőív

A szebbé teheti a világot tény fontosságát a válaszadók $53,4 \%$ vélte nagyon fontosnak, $31,5 \%$ fontosnak, $11 \%$ elég fontosnak és $1,4 \%$ kicsit fontosnak.

A válaszadók 39,7\% vélte nagyon fontosnak, 35,6\% fontosnak, 17,8\% eléggé fontosnak,és $2,7 \%$ vélte kicsit fontosnak a gondatlan élet biztositását.

Az új gondolatokkal való találkozás fontossága kérdésében a hallgatók 2,7\% véli kicsit fontosnak, 12,3\% eléggé fontosnak, 49,3\% fontosnak és 31,5\% nagyon fontosnak sz új információkat. A táblázatban látható, hogy fontos szerepet játszik a megkérdezettek életében az új gondolatokkal való találkozás. Nagyon kis mértékben van jelen az ismérv kis mértékủ lényegessége. (6. táblázat) 
6.számú táblázat Új gondolatokkal találkozhat a munka során

\begin{tabular}{|l|c|c|}
\hline Kicsit fontos & 2 & $2,7 \%$ \\
\hline Eléggé fontos & 9 & $12,3 \%$ \\
\hline Fontos & 36 & $49,3 \%$ \\
\hline Nagyon fontos & 23 & $31,5 \%$ \\
\hline Összesen & 70 & $95,9 \%$ \\
\hline Nem válaszolt & 3 & $4,1 \%$ \\
\hline Összesen & 73 & $100,0 \%$ \\
\hline
\end{tabular}

Forrás: Debreceni Egyetemen folyó Pályakép

és Munkaérték Kutatási Projekt-kérdőív 24 számú kérdése

A munkában való megbecsülés fontosságában az egyáltalán nem fontos és kicsit fontos kérdésre egyforma arányban válaszoltak a megkérdezettek 1,4\%-ban, 8,2\% -nak eléggé fontos, 47,9 \%-nak fontos és 38,4\%-nak nagyon fontos. A megbecsülés manapság legöbb esetben a javadalmazásban nyilvánul meg. A megkérdezettek esetében a legnagyobb százalék a nagyon fontos és fontos válaszokra volt jellemző.

7.számú táblázat Szüntelenül fejlesztheti tökéletesítheti önmagát

\begin{tabular}{|l|c|c|}
\hline Eléggé fontos & 4 & $5,5 \%$ \\
\hline Fontos & 25 & $34,2 \%$ \\
\hline Nagyon fontos & 42 & $57,5 \%$ \\
\hline Összesen & 71 & $97,3 \%$ \\
\hline Nem válaszolt & 2 & $2,7 \%$ \\
\hline Összesen & 73 & $100,0 \%$ \\
\hline
\end{tabular}

Pályakép és Munkaérték Kutatási Projekt

A szüntelen fejlesztheti, tökéletesitheti önmagát lehetőség fontossága a fentebbi táblázatban van összefoglalva. Amint láthatjuk a 73 megkérdezett egyetemi hallgató közül 5,5\%-nak elég fontos, $34,2 \%$ fontos és 57,5\%-nak nagyon fontos ez a lehetőség. ( 7 . táblázat) 


\section{ÖssZegZÉs}

Számos információt szerezhetünk a kérdőívek alapján azzal kapcsolatosan, hogy a 73 megkérdezett hallgató életében a pályaválasztással kapcsolatos döntést mi határozta meg, milyen szempontok érvényesültek. A kérdőívek lekérdezése során mind anyagi, mind szellemi értékekkel kapcsolatos kérdések is voltak. A kérdőívben felmerülnek olyan kérdések, melyekről úgy érzem, hogy egy bizonyos szintig egymást kizárhatnák. Ilyenek például a másokon való segítség, pénzkeresés, új gondolatokkal való találkozás. Az eredményekből látható, hogy annak ellenére, hogy kizárhatnák egymást, mégis a kérdezettek esetében nagymértékben fontos és alapvető szerepet tölt be mindkét dolog.

A megkérdezettek többsége hallgatónő. A kapott eredményeket azzal is lehet magyarázni, hogy ök érzékenyebbek a szociális problémákra, vagy feltételezhetően nem csak az anyagi vetület és a presztízs, a státusz a legfontosabb az életükben. Mindennek ellenére mégis azt állítom, hogy a nők pályaválasztásában fontos szerepe van a jövedelmek és számos más ismérvnek is. Szociális munkásként fontosnak vélem kiemelni, hogy a kutatásból kirajzolódik, hogy annak a diáknak, aki a társadalomtudományok mellett dönt, erős belső motivációja van azokkal a dolgokkal összefüggésben, amelyek a szociális szakmák lényegi vonásait jelentik.

Az életkori összetételt heterogénnek nevezném, hiszen 19 és 49 év közötti hallgatók válaszoltak a kérdőívre. Akár azt is mondhatnánk, hogy az egyetemen különböző generációkhoz tartozó személyek találkoztak, akik ugyanazt a döntést hozták meg, azaz a társadalomtudományok terén való továbbtanulás mellett döntöttek. Amit még fontosnak vélek megjegyezni, hogy az egyetemen tanuló idősebb korosztály nagyobb arányban távoktatáson folytatják tanulmányaikat. De azt is kiemelném, hogy habár alacsony százalékban $(6 \%)$ de vannak idősebb generációt képviselő diákok is akik nappali tagozaton folytatják egyetemi tanulmányaikat.

A hallgatók pályaválasztását számos tényező alakítja. A kutatás során kirajzolódott, hogy a vizsgálatban résztvevő egyetemi hallgatók miként hozták meg ezt a döntést, honnan szereztek információkat és kiknek a segítségét kérték. A pályaorientáció nagy kérdés napjainkban, mivel rengeteg egyetemi szak indul. Sok esetben fiatalokkal történő beszélgetés során kiderül, hogy miután elkezdik egyetemi tanulmányaikat, akkor döbbennek rá, hogy nem is azt nyújtja az adott szak, amit ők a választás elött elképzeltek. Egyesek ezt pozitívumként élik meg, úgy vélekednek, hogy többet kapnak, mint amire vártak, mások pedig negatívként élik meg, mivel nem azt tanulhatják a választott szakon belül amit ök szeretettek volna. 


\section{Felhaszánat irodalom}

1. Bakos, F., (1986). Idegen szavak és kifejezések szótára. Akadémiai kiadó, Budapest.

2. R. Bögös, Zsuzsanna, V. Dávid, Mária (2003) Pályaválasztási feladatok az általános és középiskolában. In: V. Dávid, Mária (szerk.): pályaválasztási információk az iskolában. B.A.Z. Megyei Munkaügyi Központ, EKF, Eger. 5-17. p.

3. Fónai Mihály (2010): Hallgatók professzió-képének elemei. In: Kozma Tamás Perjés István (szerk.): Új kutatások a neveléstudományokban. Többnyelvűség és multikulturalitás. Budapest: Aula Kiadó, pp. 227-246. 